\title{
Prediction of the solubility of recovery boiler precipitator ash
}

DANIEL SATURNINO AND HONGHITRAN

ABSTRACT: The solubility of recovery boiler precipitator ash in water is important in the design and operation of ash treatment systems used to control chloride $(\mathrm{Cl})$ and potassium $(\mathrm{K})$ accumulation in the kraft recovery cycle. We determined the solubility of mixtures of alkali salts that constitute precipitator ash and several precipitator ash samples, through laboratory experiments and theoretical simulation using a commercially available thermodynamic program. The solubility of precipitator ash in water at $85^{\circ} \mathrm{C}$ varies widely, from $400-550 \mathrm{~g} / \mathrm{L} \mathrm{H}_{2} \mathrm{O}$, depending on ash composition. The composition of the liquid portion of an ash-water slurry changes significantly with an increase in ash concentration: the $\mathrm{Cl}$ concentration increases, the sulfate $\left(\mathrm{SO}_{4}\right)$ concentration decreases, and the $\mathrm{K}$ and carbonate $\left(\mathrm{CO}_{3}\right)$ concentration remain the same. Between $30^{\circ} \mathrm{C}-100^{\circ} \mathrm{C}$, temperature has little effect on the solubility of precipitator ash and on the composition of the liquid portion of the slurry.

Application: Mills can improve control of chloride and potassium build-up in the recovery cycle by understanding the water solubility of recovery boiler precipitator ash under various conditions.

C hlorine (commonly referred to as chloride, $\mathrm{Cl}$ ) and potassium (K) are known to have a negative impact on the operation of the kraft chemical recovery process. These elements, despite their small quantities in black liquor, can drastically lower the melting temperature of carryover particles/deposits, and contribute greatly to fouling and corrosion of heat transfer tubes in the superheater region of recovery boilers.

Due to the enrichment of $\mathrm{Cl}$ and $\mathrm{K}$ in recovery boiler precipitator ash, efforts to remove them from the recovery cycle have been directed at the precipitator ash. Many mills control their $\mathrm{Cl}$ and $\mathrm{K}$ levels by purging precipitator ash periodically through their sewage systems. Ash purging is easy and requires little capital investment, but it is not a viable solution due to environmental concerns and high costs associated with sodium (Na) and sulfur (S) lost with the purged ash.

Several commercially available ash treatment processes use different principles to selectively remove $\mathrm{Cl}$ and $\mathrm{K}$ from the recovery cycle [1]. These processes include ash leaching, evaporation-crystallization, freezing-crystallization and ion exchange, and a common feature is that they all need to $\mathrm{mix}$ the ash with water to produce either ash-water slurry or a nearly saturated aqueous solution of the ash. In the ash leaching process [2], precipitator ash is mixed with water to form slurry (a mixture of liquid and solids). In the evaporation-crystallization process [3], precipitator ash is completely dissolved in water to form a nearly saturated solution. The solution is then evaporated in a crystallizer to precipitate solids, which is separated from the solution and recovered. In the freezingcrystallization process [4], instead of being heated and concentrated, the nearly saturated solution is cooled below $15^{\circ} \mathrm{C}$ to precipitate sodium sulfate decahydrate $\left(\mathrm{Na}_{2} \mathrm{SO}_{4} 10 \mathrm{H}_{2} \mathrm{O}\right)$, which is then separated and recovered. In the ion exchange process, the solution is passed through a proprietary resin bed to selectively remove $\mathrm{NaCl}[5,6]$. These processes must all deal with the solubility of the precipitator ash in water.

The composition of precipitator ash varies widely from mill to mill and from boiler to boiler, depending on mill location, wood species, degree of mill closure, liquor sulfidity, and recovery boiler operating conditions [7-9]. For inland softwood mills, precipitator ash typically consists of mainly sodium (Na) and sulfate ( $\left.\mathrm{SO}_{4}\right), 2-3 \mathrm{wt} \% \mathrm{Cl}, 3-4 \mathrm{wt} \% \mathrm{~K}$, with small amounts of char (carbon) and inert materials. For inland hardwood mills, the potassium content is higher, $6-10 \mathrm{wt} \% \mathrm{~K}$ and for coastal mills, the Cl content is much higher, $10-15 \mathrm{wt} \%$ $\mathrm{Cl}$. The carbonate $\left(\mathrm{CO}_{3}\right)$ content may vary widely from as low as $0 \mathrm{wt} \% \mathrm{CO}_{3}$ for boilers that operate at low bed temperatures and high or low sulfidity liquor, to as high as $20 \mathrm{wt} \% \mathrm{CO}_{3}$ for boilers that operate at high bed temperatures and low sulfidity liquor. This wide variation in ash composition is expected to have a great effect on the solubility of the ash.

Precipitator ash is essentially a mixture of ionic alkali salts $\left(\mathrm{Na}_{2} \mathrm{SO}_{4}, \mathrm{Na}_{2} \mathrm{CO}_{3}, \mathrm{NaCl}, \mathrm{K}_{2} \mathrm{SO}_{4}, \mathrm{~K}_{2} \mathrm{CO}_{3}\right.$, and $\left.\mathrm{KCl}\right)$. When dissolved in water, these salts dissociate into $\mathrm{Na}^{+}, \mathrm{K}^{+}, \mathrm{SO}_{4}^{2-}, \mathrm{CO}_{3}^{2-}$, and $\mathrm{Cl}$ ions. Thus, the solubility is determined mainly by ash composition and ash-water slurry temperature. Although the solubility of pure salts in water, and to some extent the solubility of salt mixtures, has been well documented [10], the solubility of precipitator ash is not well understood. Furthermore, the solubility of individual ions in the solution (e.g., the maximum concentration of $\mathrm{Cl}$ in the liquid portion of the ash-water slurry), and how may it be affected by slurry temperature and ash concentration are not known. Such information is critically important for designing and operating an ash treatment system to minimize $\mathrm{Cl}$ and $\mathrm{K}$ buildups in the chemical recovery cycle.

Our objective was to examine the solubility in water of various precipitator ash samples, as a function of ash composition, ash concentration, and solution temperature, both 
through laboratory experiments and theoretical simulation using a thermodynamic computer program. We describe the program and its capability and discuss the key results we obtained from the program predictions and experiments and their implications.

\section{THE PROGRAM}

The advanced thermodynamic program we used is OLI Stream Analyzer v. 2.0.31, commercially available software designed for aqueous solution applications $[11,12]$. The program is generally used for predicting complex chemical and electrochemical phenomena in aqueous and mixed solvent solutions. The program's predictive thermodynamic model is based on published experimental data. It uses data regression where applicable and estimation and extrapolation where required and can predict composition and concentration for ionic salt mixtures in water over a wide range of temperature, pressure, and ionic strength.

The input parameters are water and ash amounts (or individual salts), ash composition, and solution temperature. The output parameters are amounts and compositions of solids and liquid (solution), which can then be used to calculate the solubility of ash or salt mixtures.

We tested the program's suitability for use in predicting the solubility of precipitator ash in water by using it to predict the solubility of pure compounds. We compared the predicted results with data obtained from literature. The tested program was then used to predict the solubility of salt mixtures and precipitator ashes, and the predicted results were again compared with literature or experimental data.

\section{RESULTS AND DISCUSSION}

\section{Solubility of pure compounds}

Figure 1 shows the solubility of $\mathrm{Na}_{2} \mathrm{SO}_{4}$ in water predicted by the program (solid line), together with literature data [13], as a function of temperature between $0-100^{\circ} \mathrm{C}$. The results are in excellent agreement with each other, showing that the solubility of $\mathrm{Na}_{2} \mathrm{SO}_{4}$ increases from $90 \mathrm{~g} / \mathrm{kg} \mathrm{H}_{2} \mathrm{O}$ at $0^{\circ} \mathrm{C}$ to about $500 \mathrm{~g} / \mathrm{kg} \mathrm{H}_{2} \mathrm{O}$ at $40^{\circ} \mathrm{C}$, with sodium decahydrate $\left(\mathrm{Na}_{2} \mathrm{SO}_{4} 10 \mathrm{H}_{2} \mathrm{O}\right)$ as the equilibrium solid phase. Above $40^{\circ} \mathrm{C}$, the solubility decreases slightly, with $\mathrm{Na}_{2} \mathrm{SO}_{4}$ as an equilibrium solid phase. Predictions were also performed on all other pure compounds (i.e., $\mathrm{Na}_{2} \mathrm{CO}_{3}, \mathrm{NaCl}, \mathrm{K}_{2} \mathrm{SO}_{4}, \mathrm{~K}_{2} \mathrm{CO}_{3}$, and $\mathrm{KCl}$ )

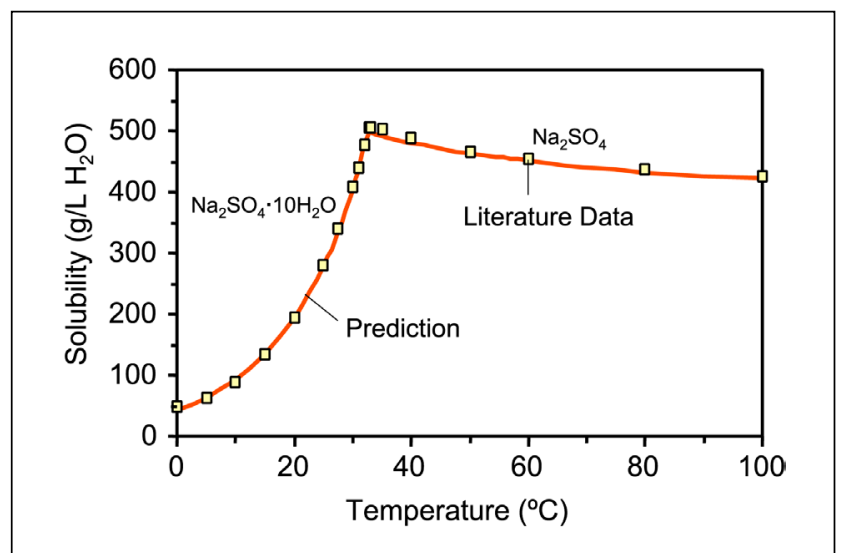

1. Comparison between the solubility of $\mathrm{Na}_{2} \mathrm{SO}_{4}$ in water at different temperatures predicted by the program and literature data [13].

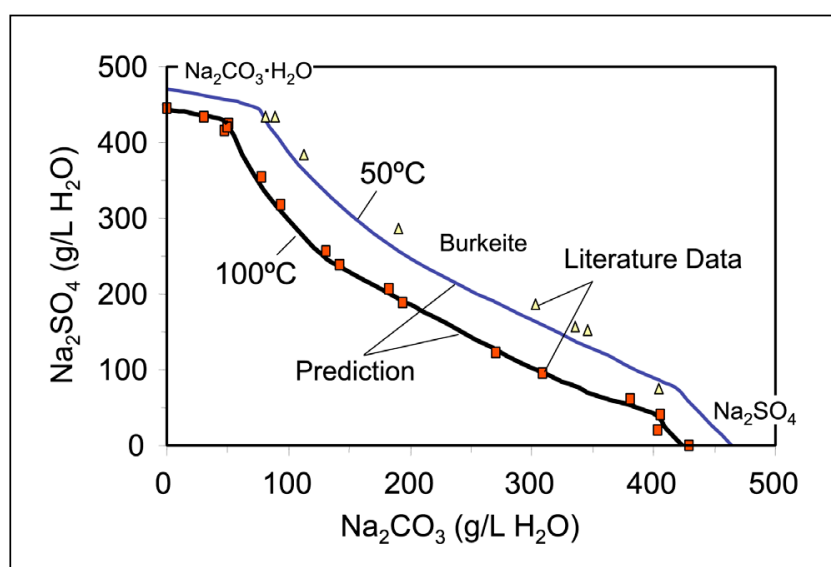

2. Comparison between the solubility of $\mathrm{Na}_{2} \mathrm{SO}_{4}-\mathrm{Na}_{2} \mathrm{CO}_{3}$ mixtures in water at 50 and $100^{\circ} \mathrm{C}$ predicted by the program and literature data [14].

and in all cases, the predicted results were very close to literature data.

\section{Solubility of mixtures of compounds}

Figure 2 shows the solubility of a binary mixture $\mathrm{Na}_{2} \mathrm{SO}_{4}$ $\mathrm{Na}_{2} \mathrm{CO}_{3}$ in water predicted by the program (solid curves), together with literature data $[14]$ at $50^{\circ} \mathrm{C}$ and $100^{\circ} \mathrm{C}$. The predictions were again in good agreement with literature data.

Table I shows similar results for various tertiary mixtures.

Over 180 predictions were performed using the program

\begin{tabular}{|c|c|c|c|c|}
\hline $\begin{array}{c}\text { Temp. } \\
\left({ }^{\circ} \mathrm{C}\right)\end{array}$ & $\begin{array}{l}\text { Composition (wt \%) } \\
\mathrm{NaCl}-\mathrm{Na}_{2} \mathrm{SO}_{4}-\mathrm{Na}_{2} \mathrm{CO}_{3}\end{array}$ & Precipitated salt & $\begin{array}{c}\text { Model prediction } \\
\left(\mathrm{g} / \mathrm{kg} \mathrm{H} \mathrm{H}_{2} \mathrm{O}\right)\end{array}$ & $\begin{array}{l}\text { Literature [10] } \\
\left(\mathrm{g} / \mathrm{kg} \mathrm{H} \mathrm{H}_{2} \mathrm{O}\right) \\
\end{array}$ \\
\hline 35 & $46-5-49$ & Burkeite/ $\mathrm{NaCl}$ & 528 & 501 \\
\hline 35 & $70-11-19$ & $\mathrm{NaCl} / \mathrm{Na}_{2} \mathrm{SO}_{4} /$ Burkeite & 444 & 441 \\
\hline 100 & $10-13-77$ & $\mathrm{Na}_{2} \mathrm{CO}_{3}{ }^{*} \mathrm{H}_{2} \mathrm{O} /$ Burkeite & 477 & 481 \\
\hline 100 & $40-8-52$ & $\mathrm{Na}_{2} \mathrm{CO}_{3}{ }^{*} \mathrm{H}_{2} \mathrm{O} /$ Burkeite & 466 & 473 \\
\hline 100 & $57-5-38$ & $\mathrm{Na}_{2} \mathrm{CO}_{3}{ }^{*} \mathrm{H}_{2} \mathrm{O} /$ Burkeite & 466 & 473 \\
\hline 100 & $26-66-8$ & Burkeite/ $/ \mathrm{NaCl}$ & 494 & 494 \\
\hline 100 & $26-69-5$ & Burkeite/ $\mathrm{NaCl}$ & 495 & 476 \\
\hline 100 & $7-83-10$ & Burkeite/ $\mathrm{NaCl}$ & 451 & 441 \\
\hline
\end{tabular}




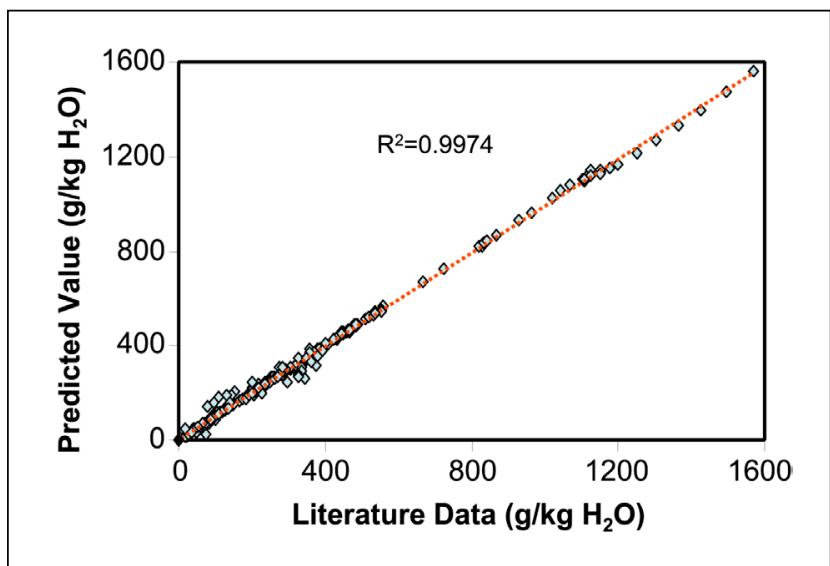

3. Comparison between model prediction and literature data (over 180 predictions).

on single compounds and various mixtures of compounds. Figure 3 shows the predicted values agreed very well with literature data, which suggests that the program is capable of predicting the solubility of recovery boiler precipitator ash.

\section{Solubility of precipitator ash}

In her study of factors affecting $\mathrm{Cl}$ and $\mathrm{K}$ removal from recovery boiler precipitator ash using a leaching method [15], Goncalves determined the compositions of six ash samples collected from different recovery boilers (Table II), and the compositions (i.e., the concentrations of $\mathrm{Na}^{+}, \mathrm{K}^{+}, \mathrm{SO}_{4}^{2-}, \mathrm{CO}_{3}^{2-}$, and $\mathrm{Cl}$ ) of the liquid and solids of each ash-water slurry prepared at $85^{\circ} \mathrm{C}$ and at an ash concentration of $800 \mathrm{~g} / \mathrm{kg} \mathrm{H}_{2} \mathrm{O}$. The experimental conditions were the same as those used in the ash-leaching process at a kraft pulp mill in Brazil $[15,16]$.

Using the test results, Goncalves determined the ash solubility (in $\mathrm{g} / \mathrm{kg} \mathrm{H}_{2} \mathrm{O}$ ) by subtracting the amount of solids

\begin{tabular}{|c|c|c|c|c|c|}
\hline Ash & \multicolumn{5}{|c|}{ Composition (wt \%) } \\
\hline & $\mathrm{Na}$ & $\mathrm{K}$ & $\mathrm{Cl}$ & $\mathrm{CO}_{3}$ & $\mathrm{SO}_{4}$ \\
\hline $\mathrm{A}$ & 29.3 & 5.6 & 6.6 & 1.2 & 56.9 \\
\hline $\mathrm{B}$ & 28.8 & 5.8 & 5.9 & 0.3 & 58.7 \\
\hline $\mathrm{C}$ & 31.5 & 5.2 & 5.4 & 12.4 & 45.5 \\
\hline $\mathrm{D}$ & 28.8 & 5.9 & 1.1 & 2.7 & 61.5 \\
\hline $\mathrm{E}$ & 27.8 & 6.7 & 3.4 & 0.1 & 61.5 \\
\hline $\mathrm{F}$ & 30.2 & 5.8 & 8.3 & 6.4 & 48.8 \\
\hline
\end{tabular}

II. Composition of precipitator ash from six recovery boilers.

\begin{tabular}{|c|c|c|}
\hline Ash & \multicolumn{2}{|c|}{ Solubility at $\left.\mathbf{8 5}^{\circ} \mathbf{C} \mathbf{~} \mathbf{g} / \mathbf{L ~} \mathbf{~}_{\mathbf{2}} \mathbf{O}\right)$} \\
\hline & Experiment [14] & Prediction \\
\hline A & 430 & 460 \\
\hline B & 440 & 482 \\
\hline C & 426 & 422 \\
\hline D & 484 & 501 \\
\hline E & 488 & 455 \\
\hline F & 478 & 500 \\
\hline Ave. & 458 & 470 \\
\hline
\end{tabular}

III. Solubility in water of precipitator ash from various boilers.

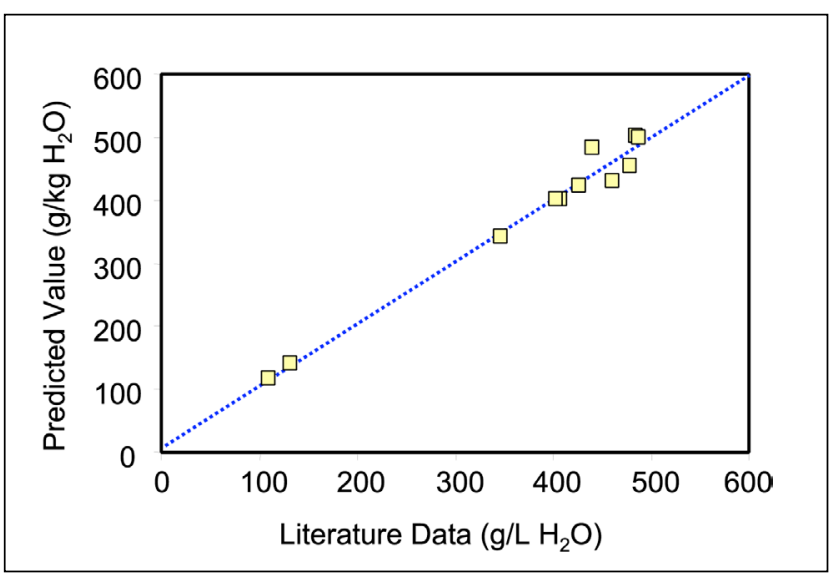

4. Comparison between model predictions and experimental measurements of solubility in water for various precipitator ash samples at different temperatures obtained by Goncalves [14] and in this study.

$\left(\mathrm{M}_{\text {solids }}\right.$, in $\left.\mathrm{g}\right)$ in the slurry from the total amount of ash added $\left(\mathrm{M}_{\mathrm{Ash}}\right.$, in $\left.\mathrm{kg}\right)$, and dividing the difference by the total mass (or volume) of the water used $\left(\mathrm{M}_{\text {Water }}, \mathrm{kg}\right.$ ), as in Eq. 1:

Solubility $=\frac{\mathrm{M}_{\text {Ash }}-\mathrm{M}_{\text {Solids }}}{\mathrm{M}_{\mathrm{Water}}}$

$\mathrm{M}_{\text {Solids }}$ is essentially the amount of the wet cake remaining on the filter paper after the ash-water slurry has been vacuumfiltered to remove the liquid, minus the amount of liquid in the wet cake. This liquid amount is equal to the amount of water in the cake (determined by evaporation), multiplied by the specific gravity of the liquid of the $0.8 \mathrm{~kg} / \mathrm{kg}$ ash-water slurry that has been predetermined for each ash at $85^{\circ} \mathrm{C}$.

Table III summarizes the experimental results, along with solubility values predicted by the program based on the ash composition in Table II. Figure 4 plots the predicted and measured solubility values for these six precipitator ash samples and five additional other ash samples we investigated and shows they are in good agreement.

\section{Effect of temperature and ash concentration}

We used the program to examine the effect of temperature and ash concentration on $\mathrm{Cl}$ and $\mathrm{K}$ dissolution in ash leaching tests. Figure 5 shows the effect of temperature on the composition of the liquid portion (the solution) of the slurry prepared from Ash "A" with an ash concentration of $800 \mathrm{~g} / \mathrm{kg}$ $\mathrm{H}_{2} \mathrm{O}$. The predictions (bars) were consistent with experimental data (points with error bars) obtained by Goncalves [15], showing that temperature has little effect on the liquid composition, i.e., the concentration of each ash component in the liquid does not appreciably change between $60^{\circ} \mathrm{C}$ and $100^{\circ} \mathrm{C}$. For example, the concentration of $\mathrm{Na}$ decreased only slightly from $28.4 \mathrm{wt} \%$ at $60^{\circ} \mathrm{C}$ (the leftmost bar) to 27.3 at $100^{\circ} \mathrm{C}$ (the rightmost bar), while the concentration of $\mathrm{Cl}$ increased from $9.6 \mathrm{wt} \%$ at $60^{\circ} \mathrm{C}$ to $9.7 \mathrm{wt} \%$ at $100^{\circ} \mathrm{C}$. The predicted $\mathrm{Cl}$ concentration, however, was consistently lower than the experimen- 


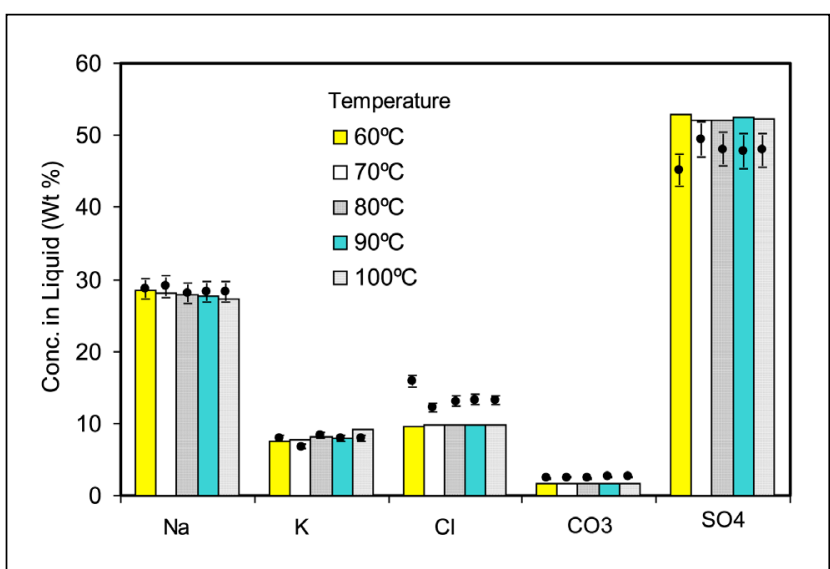

5. Composition of the liquid of Ash" A" slurry (800 $\mathrm{g} / \mathrm{L}$ water) in a temperature range of $60-100^{\circ} \mathrm{C}$. Bars are predicted values. Data points and error bars are experimental values.

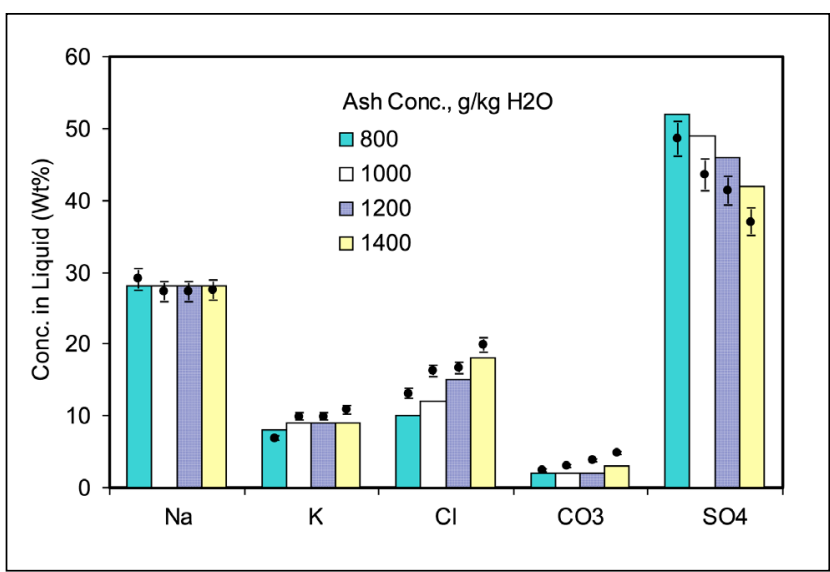

6. Liquid composition of ash " $A$ " slurry at $85^{\circ} \mathrm{C}$ as a function of ash concentration. Bars are predicted values. Data points and error bars are experimental values.

tal data, whereas the predicted $\mathrm{SO}_{4}$ concentration was consistently higher than the experimental data by the same amount that has been under-predicted for the $\mathrm{Cl}$ concentration. The cause of this discrepancy is not known, although it is likely due to the inaccuracy in the $\mathrm{Cl}$ and $\mathrm{SO}_{4}$ analytical procedures.

Figure 6 shows the effect of ash concentration on the composition of liquid of Ash "A" slurry prepared at $85^{\circ} \mathrm{C}$. Again, the predictions were consistent with experimental data, showing little change in $\mathrm{Na}, \mathrm{K}, \mathrm{CO}_{3}$ contents in the liquid with an increase in ash concentration, while the $\mathrm{SO}_{4}$ content decreased and the $\mathrm{Cl}$ content increased markedly.

Because the program predicted well the liquid composition for all ash leaching tests, we performed further simulations to evaluate the effects of temperature from $0-100^{\circ} \mathrm{C}$ and ash concentration from $200-1400 \mathrm{~g} / \mathrm{kg} \mathrm{H}_{2} \mathrm{O}$. Figure 7 shows the simulation results at different temperatures for Ash " $\mathrm{A}$ " with ash concentration of $800 \mathrm{~g} / \mathrm{kg} \mathrm{H}_{2} \mathrm{O}$. Above $30^{\circ} \mathrm{C}$, the liquid composition is not changed with temperature, as suggested in Fig. 5. Below $30^{\circ} \mathrm{C}$, however, the composition changes dramatically; the $\mathrm{SO}_{4}$ concentration in the liquid decreases from $55 \%$ at $30^{\circ} \mathrm{C}$ to less than $10 \%$ at $0^{\circ} \mathrm{C}$ and the $\mathrm{Cl}$ concen-

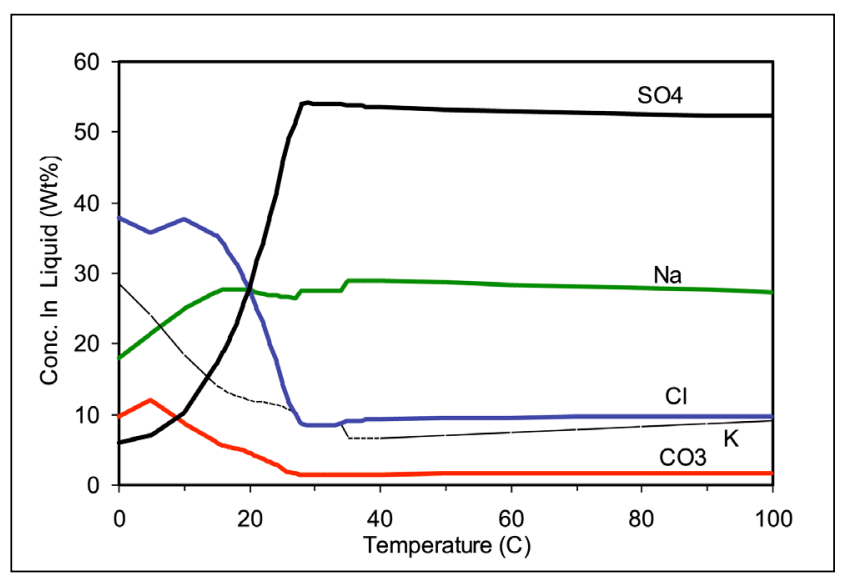

7. Effect of temperature on liquid composition of Ash "A" slurry $(800 \mathrm{~g} / \mathrm{L}$ water), as predicted by the program.

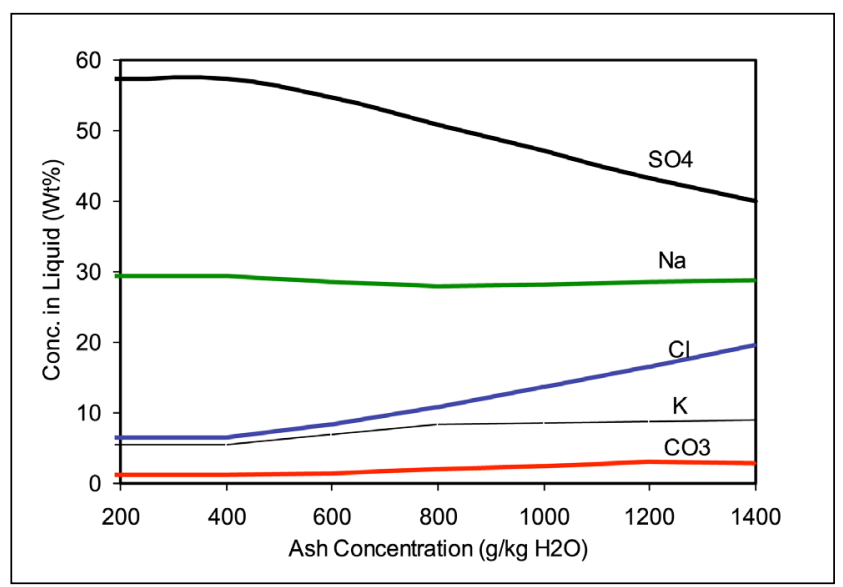

8. Effect of ash concentrations on liquid composition of Ash " $A$ " slurry at $85^{\circ} \mathrm{C}$, as predicted by the program.

tration increases from $10 \%$ to about $40 \%$. Figure 8 shows the liquid composition as a function of ash concentration in Ash " $\mathrm{A}$ " slurry at $85^{\circ} \mathrm{C}$. The $\mathrm{SO}_{4}$ concentration decreased and the $\mathrm{Cl}$ content increased as the ash concentration increased.

\section{RECYCLING TESTS}

Results shown in Fig. 8 also suggest that ash slurry with a higher $\mathrm{Cl}$ concentration would contain less $\mathrm{SO}_{4}$. Thus, it may be possible to improve the $\mathrm{Cl}$ removal efficiency and the $\mathrm{SO}_{4}$ recovery efficiency of an ash-leaching system by recycling the liquid back to the ash slurry tank. In order to verify this possibility, we conducted recycling tests along with simulations using the program.

The tests were performed on two ash samples, one with a low carbonate content, $0.3 \mathrm{wt} \% \mathrm{CO}_{3}$ (Ash "B") and the other with a high carbonate content, $12.4 \mathrm{wt} \% \mathrm{CO}_{3}$ (Ash "C"), as shown in Table II. Figure 9 schematically shows the recycling test procedure for Ash "B". After each recycling test, $80 \%$ of the liquid, which has been separated from the slurry, was used along with $20 \%$ fresh water to dissolve the fresh ash in the subsequent test. 


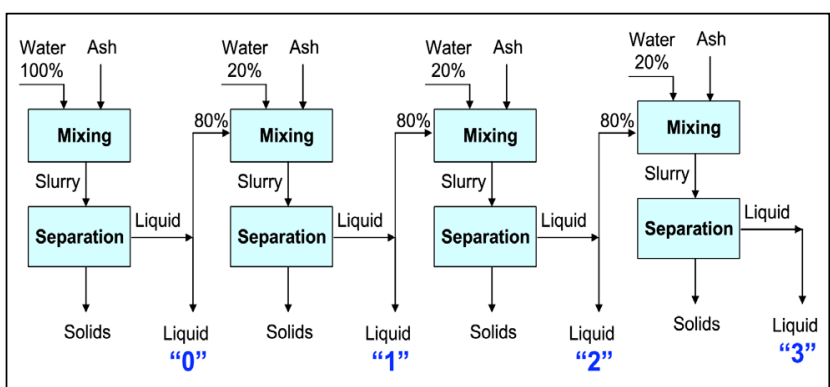

9. Recycling test procedure for Ash " $B$ ".

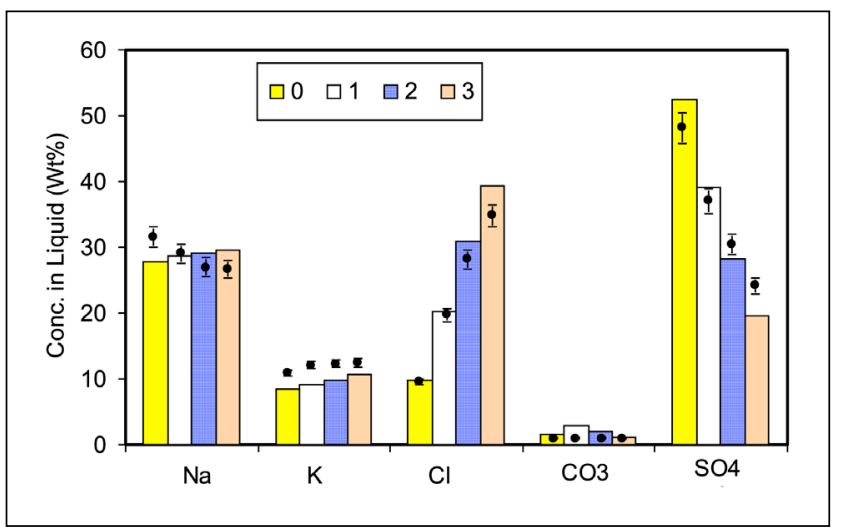

10. Change in liquid composition of Ash " $B$ " (low carbonate) slurry at $85^{\circ} \mathrm{C}$ and ash concentration of $800 \mathrm{~g} / \mathrm{kg} \mathrm{H} \mathrm{H}_{2} \mathrm{O}$ with number of recycles; $80 \%$ liquid recycling.

Figure 10 shows the change in liquid composition with each recycling test for Ash " $\mathrm{B}$ " at $85^{\circ} \mathrm{C}$ and at an ash concentration of $800 \mathrm{~g} / \mathrm{kg} \mathrm{H}_{2} \mathrm{O}$. Number 0 means without recycling and numbers 1, 2, and 3, respectively, represent the first, second, and third cycles. The bars represent the values calculated by the program and the dots and error bars are the experimental values. The results show clearly that for this ash, the $\mathrm{Na}$ and $\mathrm{CO}_{3}$ concentrations in the liquid did not change much with the number of recycling tests. The potassium concentration increased only slightly, while the chloride concentration increased and the sulfate concentration decreased markedly. This is important, as it implies that the $\mathrm{Cl}$ removal efficiency and the $\mathrm{SO}_{4}$ recovery efficiency of an ash-leaching system can be significantly improved by recycling a portion of the liquid back to the ash-water slurry tank.

Figure 11 shows results of the recycling test for Ash "C". In this case, the ash concentration in the slurry was $500 \mathrm{~g} / \mathrm{kg}$ $\mathrm{H}_{2} \mathrm{O}$ and only $50 \%$ of the liquid was recycled. The change in test conditions was necessary due to the high carbonate content of Ash "C" that makes it much more difficult to separate the liquid from the slurry, compared with Ash "B". The results were similar to those for Ash "B", although the increase in chloride concentration and the decrease in sulfate concentration in the liquid with increased number of recycling were much smaller. This is probably due to the lower concentration of Ash "C" in water and smaller volume of liquid used in the Ash "C" experiments.

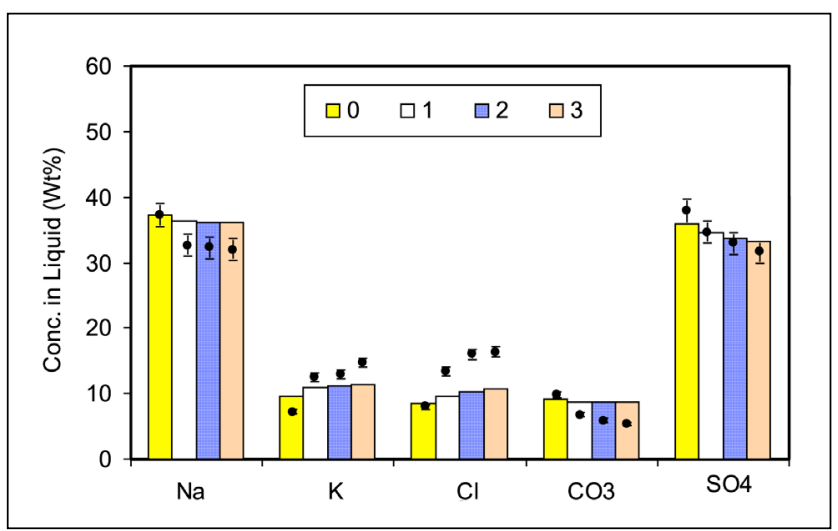

11. Change in liquid composition of Ash "C" (high carbonate) slurry at $85^{\circ} \mathrm{C}$ and ash concentration of $500 \mathrm{~g} / \mathrm{kg} \mathrm{H} \mathrm{H}_{2} \mathrm{O}$ with number of recycle; $50 \%$ liquid recycling.

\section{SUMMARY AND CONGLUSIONS}

We used an advanced thermodynamic-based computer program to examine the solubility of precipitator ash in water, as a function of ash composition, ash concentration, and solution temperature. The results show that:

- The predicted values by the program are in good agreement with literature and experimental data.

- The solubility of precipitator ash at $85^{\circ} \mathrm{C}$ is about 470 $\mathrm{g} / \mathrm{L}_{2} \mathrm{O}$. It varies widely from $400-550 \mathrm{~g} / \mathrm{L} \mathrm{H}_{2} \mathrm{O}$, depending on the carbonate content of the ash.

- In the ash concentration range of $0.8-1.4 \mathrm{~kg} / \mathrm{L}$, the composition of the liquid portion of an ash-water slurry changes significantly with an increase in ash concentration in the slurry: the $\mathrm{Cl}$ concentration increases, the sulfate concentration decreases, and the potassium and carbonate concentrations remain the same.

- Between $30^{\circ} \mathrm{C}$ and $100^{\circ} \mathrm{C}$, temperature has little effect on the solubility of precipitator ash and on the composition of the liquid portion of the slurry. Below $30^{\circ} \mathrm{C}$, it has a significant effect.

- For precipitator ash with low carbonate contents, the $\mathrm{Cl}$ removal efficiency and the $\mathrm{SO}_{4}$ recovery efficiency may be improved by recycling a portion of the liquid back to the ash-water slurry tank.

\section{ACKNOWLEDGEMENTS}

This work was part of the research program Increasing Energy and Chemical Recovery Efficiency in the Kraft Process, jointly supported by the Natural Sciences and Engineering Research Council of Canada (NSERC) and a consortium of the following companies: Abitibi Bowater, Alstom Power, Andritz, Aracruz Celulose, Babcock \& Wilcox, Boise Paper Solutions, Carter Holt Harvey, Celulose Nipo-Brasileira, Clyde-Bergemann, Diamond Power International, Domtar, DMI Peace River Pulp, Georgia Pacific, International Paper, Irving Pulp \& Paper, MeadWestvaco, Metso Power, Stora Enso Research, Tembec, and Votorantim Celulose e Papel. TJ 
Received: March 6, 2008

Accepted: August 10, 2008

\section{LITERATURE CITED}

1. Tran, H.N. and Earl, P.F., Chloride and potassium removal processes for kraft pulp mills: a technical review, 2004 International Chemical Recovery Conference Proceedings, TAPPI PRESS, Atlanta, Georgia, USA, 2004.

2. Knutsson, M., Eriksson, M., Sartório, C.C., Hilber, V.R., and Filho, O.M., Experiences from first start-up of an ash leaching system, 2002 TAPPI Fall Technical Conference Proceedings, TAPPI PRESS, Atlanta, Georgia, USA, 2002.

3. Earl, P.F., Dick, P.D., and Patel, J-C., Removal of chloride and potassium from the kraft recovery cycle, presented at the 1995 CPPA Pacific Coast \& Western Branches Technical Conference, Whistler, British Columbia, Canada, May 18-20, 1995

4. Fujisaki, A., Tateishi, Y, and Baba, Y., Pulp Paper Can. 104(1): T1(2003).

5. Brown, C.J. and Paleologou, M., Pulp Paper Can. 100(8): T251(1999).

6. Jemma, J., Tan, G., Thibault A., Paeologou, M., Adderley, R., Baxter, G., et. al., Demonstration of the precipitator dust purification system at Tembec's Skookumchuk kraft pulp mill, 2007 International Chemical Recovery Conference Proceedings, PAPTAC/ TAPPI, Quebec City, Quebec, 2007.

7. Tran, H.N., Barham, D., and Reeve, D.W., Pulp Paper Can. 91(5): 55(1990)

8. Duhamel, M., Tran, H.N., and Frederick, W.J., "The Sintering Tendency of Recovery Boiler Precipitator Dusts," Tappi Journal, Vol.3, No. 10, p.25-29 (2004).

9. Hupa, M., Backman, R., Skrifvars, B.-J., and Forssen, M., J. Pulp Paper Sci., 27(12): 416(2001).

10. Linke, W.F. and Seidell, A., Solubilities of inorganic and metalorganic compounds: a compilation of solubility data from the periodical literature, 4th edn., Van Nostrand, Princeton, New Jersey, USA, 1965.

11. http://www.olisystems.com

12. Wang, P., Anderko, A., and Young, R.D., Fluid Phase Equilibria, 203: 141(2002).

13. Perry, R.H. and Chilton, C.H., Chemical Engineers' Handbook, 4th edn., McGraw Hill, New York, New York, USA, 1984.

14. Green, S.J. and Frattali, F.J., J. Am. Chem. Soc., 68(9): 1789(1946).

15. Goncalves, C., Tran, H.N., and Shenassa, R., Factors affecting the removal efficiency of $\mathrm{Cl}$ and $\mathrm{K}$ from recovery boiler precipitator ash, 2007 International Chemical Recovery Conference Proceedings, PAPTAC/ TAPPI, Quebec City, Quebec, Canada, 2007.

16. Goncalves, C., Tran, H.N., Braz, S., Puig, F, and Shenassa, R., Pulp Paper Can., 109(3): 33(2008).

\section{INSIGHTS FROM THE AUTHORS}

The solubility of recovery boiler precipitator ash in water is an important parameter in the design and operation of ash treatment systems. This study is a good complement to our research on chemical recovery, particularly the efficiency of ash treatment systems and the effect of $\mathrm{Cl}$ and $\mathrm{K}$ on recovery boiler fouling.

Our biggest challenge was to obtain sufficient experimental data to validate our OLI basethermodynamic model. We addressed it by performing numerous experiments in our laboratory and by conducting an extensive literature survey on the water-solubility of relevant salts and their mixtures.

Interestingly, we found that the concentration of chloride in the liquid portion of an ash-water

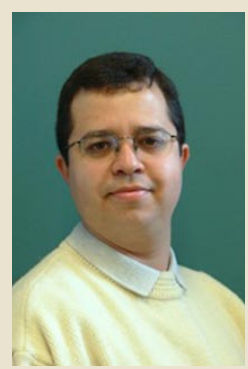

Saturnino

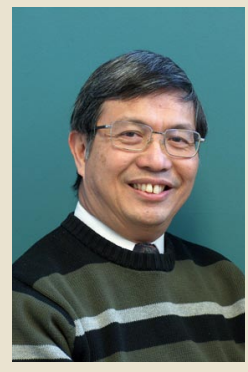

Tran slurry increased, while that of sulfate decreased, with an increase in ash concentration in the slurry. Mills might use this information to increase their $\mathrm{Cl}$ removal efficiency and sulfur recovery efficiency by controlling the $\mathrm{Cl}$ and $\mathrm{K}$ concentrations in the liquor cycle.

Saturnino is a PhD Candidate with the Pulp and Paper Centre, University of Toronto, Toronto, ON, Canada. Tran is Frank Dottori Professor of Pulp \& Paper Engineering, Department of Chemical Engineering and Applied Chemistry, and Pulp \& Paper Centre Director at the University of Toronto, Toronto, ON, Canada; email Tran at honghi.tran@utoronto.ca. 